\title{
Preface: Coastal wetlands: services, uses, and conservation
}

\author{
Dong Xie $\mathbb{B} \cdot$ Shuqing An · Jennifer Ann Davis
}

Received: 30 August 2018/Revised: 30 August 2018/Accepted: 19 September 2018/Published online: 8 November 2018 (C) Springer Nature Switzerland AG 2018

Coastal wetland is an ecotone between the ocean and the land. It has both marine and terrestrial ecological characteristics and is an important part of the wetland ecosystem. It is rich in biodiversity and is the habitat and breeding ground for many offshore marine organisms. It is the "transfer station" for migratory birds, also is an important buffer zone for global environmental change. However, the deterioration of the coastal wetland ecological environment brings about a series of chain reactions. In this special section, we focused on services, uses, and conservation of coastal wetlands. We hope such section can reflect current research advances in the areas of coastal wetlands.

Guest editors: Shuqing An, Jennifer Ann Davis \& Dong Xie / Coastal Wetlands: Services, Uses and Conservation

\section{Xie $(\bowtie)$}

Co-Innovation Center for Sustainable Forestry in

Southern China, Nanjing Forestry University,

Nanjing 210037, Jiangsu, China

e-mail: xiedong0123@gmail.com

\section{S. An}

School of Life Science, Nanjing University,

Nanjing 210046, Jiangsu, China

\section{J. A. Davis}

School of Environment, Charles Darwin University, Casuarina, NT 0810, Australia
To test whether coupled elements shifted equally and discuss the possible strategy adopted by coastal plants in maintaining their nutrient balance, Liu et al. (2017, this issue) performed an experiment on Suaeda salsa in three supratidal habitats of Tianjin, China. They found a high salt stress limited the photosynthetic $\mathrm{C}$ gain, which reduced plant $\mathrm{C}: \mathrm{N}, \mathrm{C}: \mathrm{S}$, and $\mathrm{P}: \mathrm{S}$ and increased $\mathrm{C}: \mathrm{P}$ and $\mathrm{N}: \mathrm{P}$ ratios in clay soils. They concluded that the plant communities in different habitats keep nutrient balance by a similar mechanism (e.g., $\mathrm{N}$ limited).

Li et al. (2017, this issue) used long-term field data to explore how suitable habitat and population size of Red-crowned crane Grus japonensis respond to coastal reclamation. They found that under the pressure of long-term coastal reclamation, the decline of suitable habitat of $G$. japonensis was affected by the increasing levels of human disturbance and the decreasing availability of natural habitat. Their results highlight the importance of considering the long-term effects of coastal reclamation on both populations and suitable habitat of coastal birds.

To improve the understanding of the carbon cycling in response to imminent sea-level rise and saltwater intrusions, Luo et al. (2017, this issue) reviewed references on the likely effects of the increasing salinity and inundation on organic carbon mineralization in tidal wetlands. They conclude that future studies should address the combined effects of salinity 
and inundation on carbon biogeochemistry in lowlevel salinity tidal wetlands.

Xie et al. (2018, this issue) explored the effectiveness of irrigation with either freshwater or seawater in achieving revegetation on degraded bare flats in the Yellow River Delta. Their results showed that the reestablishment of plant seedlings could occur on bare flats when the two essential thresholds are exceeded, which give us information on predicting the effectiveness of restoration efforts for future restoration efforts on bare flats.

Wang et al. (2017, this issue) examined impacts of Macondo MC252 oil from the Deepwater Horizon spill on oil-degrading bacteria in fresh and oligohaline marshes dominated by the common reed Phragmites australis (Cav.) Trin. ex Steud. and correlated microbial changes to soil variables. They found that indigenous oil-degrading bacteria effectively responded to weathered Macondo oil in the $P$. australis marsh soil wherein GP bacteria with PAHRHD $\alpha$ genes played a major role in biodegradation of PAH-enriched petroleum hydrocarbons.

Litter decomposition plays a crucial role in aquatic food webs. Kong et al. (2018, this issue) used a specially designed bucket to investigate the direct (grazing) and indirect (feces) effects of shrimp Neocaridina denticulata (a common shrimp in East Asia wetlands) on the decomposition of Typha angustifolia (a emergent macrophyte, widely distributed) litters. Their results demonstrated that some aquatic animals, like shrimp, not only breakdown leaf litters by grazing, but also stimulate the microbial activities by their byproducts such as feces.
We thank all Hydrobiologia editors and their collaborators for producing the present collection of papers; all editors that assisted in the review process; all reviewers that have reviewed these manuscripts, as well as the staff of Springer for production.

\section{References}

Kong, X., W. Wu, K. Tian, Y. Jia, A. Siddiq, H. Lin \& X. Tian, 2018. Promotive performance of shrimp Neocaridina denticulata on Typha angustifolia leaf litter decomposition. Hydrobiologia. https://doi.org/10.1007/s10750-0183573-4.

Liu, F., Y. Zheng, Y. Liu, Y. Dong, D. Li \& M. Wang, 2017. Stoichiometric nutrient balance of Suaeda salsa wetlands in different supratidal habitats of Tianjin, China. Hydrobiologia. https://doi.org/10.1007/s10750-017-3351-8.

Li, N., Z. Wang, L. Xia, F. Yan, L. Xu, Y. Qiao, X. Li, S. An \& S. Fang, 2017. Effects of long-term coastal reclamation on suitable habitat and wintering population size of the endangered Red-crowned Crane, Grus japonensis. Hydrobiologia. https://doi.org/10.1007/s10750-017-3341$\mathrm{x}$.

Luo, M., J. F. Huang, W. F. Zhu \& C. Tong, 2017. Impacts of increasing salinity and inundation on rates and pathways of organic carbon mineralization in tidal wetlands: a review. Hydrobiologia. https://doi.org/10.1007/s10750-017-34168.

Wang, J., C. R. Judy \& A. Hou, 2017. The responses of indigenous oil-degrading bacteria to oil exposure in Phragmites australis-dominated marsh soil: a mesocosm study. Hydrobiologia. https://doi.org/10.1007/s10750-0173461-3.

Xie, T., B. Cui, S. Li \& S. Zhang, 2018. Management of soil thresholds for seedling emergence to re-establish plant species on bare flats in coastal salt marshes. Hydrobiologia. https://doi.org/10.1007/s10750-018-3589-9. 